\title{
PENGARUH ASUHAN KEPERAWATAN KELUARGA TERHADAP STATUS GIZI BALITA DI WILAYAH KERJA PUSKESMAS CIPANAS GARUT
}

\author{
Nina Sumarni ${ }^{1}$, Witdiawati², Ema Arum Rukmasari ${ }^{3}$ \\ Email : n.sumarni@unpad.ac.id \\ 1,2,3 Fakultas Keperawatan Universitas Padjadjaran Kampus Garut \\ J1.Proklamasi No 5 Garut \\ Telp. (0262) 232212
}

\begin{abstract}
Abstrak
Kualitas sumber daya manusia sangat erat terkait erat dengan kemampuan masyarakat untuk memenuhi kebutuhan pangan dengan gizi seimbang, pemenuhan gizi seimbang diperlukan sejak janin sampai usia lima tahun karena masa ini merupakan masa rawan bagi anak.Anak dengan status gizi kurang sebaiknya mendapat perhatian dari petugas kesehatan agar tidak terjadi gizi buruk.Untuk keberhasilan perawatan balita gizi kurang ditingkat rumah tangga diperlukan partisifasi dari petugas kesehatan dengan memberikan bimbingan, bantuan dan pendampingan bagi keluarga melalui kunjungan petugas dan memafaatkan potensi keluarga dalam pemecahan masalah.Adapun Jumlah Balita diwilayah ini 3.160 orang dan 325 orang mengalami gizi kurang. Tujuan mengetahui pengaruh asuhan keperawatan keluarga terhadap status gizi Balita

Rancangan penelitian dengan quasi ekperimental, Besaran sampel 66 orang, kelompok perlakuan 66 orang, kelompok kontrol 65 ,pengumpulan data dilakukan dengan kunjungan pada keluarga sebelum dan sesudah pembinaan. Analisa data menggunakan uji Wilcoxon.

Hasil Penelitian pada analisi univariat variabel pengetahuan setelah perlakuan $40 \%$ sangat baik. Sikap 17\% kurang mendukung. Setelah perlakukan satu bulan , 23 balita status gizi balita berubah menjadi gizi baik. Perubahan status gizi pada kelompok perlakuan rata-rata meningkat 0,23 dari Z-skor semula, dan kelompok kontrol meningkat 0,04 dari Z-skor semula.Kesimpulan melalui asuhan kepewatan keluarga dapat meningkatkan pengetahuan, sikap dan status gizi balita.
\end{abstract}

Kata kunci:Asuhan, Balita,Gizi kurang.

\section{Pendahuluan}

Kemiskinan yang dialami sebagian penduduk memang berdampak sangat serius terhadap status gizi anggota keluarga mereka, khususnya kelompok anak. Kasus status gizi kurang pada Balita juga bisa ditemukan pada keluarga yang secara materi tergolong kaya, hal ini disebabkan perilaku hidup bersih dan sehat tidak sesuai dengan standar kesehatan (Dinkes Kabupaten Garut, 2015) ${ }^{[1]}$ Pemerintah Kabupaten Garut melalui Dinas Kesehatan berupaya untuk menanggulangi masalah gizi dengan mengeluarkan kebijakan, strategi, rencana kegiatan yang harus ditindak lanjuti oleh petugas Puskesmas. Namun karena keterbatasan tenaga dan luasnya wilayah, program penanggulangan gizi tersebut kurang berhasil. Upaya peningkatan kualitas sumber daya manusia sangat terkait dengan kemampuan masyarakat untuk memenuhi kebutuhan pangan dengan gizi yang seimbang. Pemenuhan kebutuhan gizi seimbang terutama diperlukan sejak janin sampai anak berusia lima tahun, karena masa ini merupakan masa rawan bagi anak atau sering disebut dengan Golden age.Anak menderita malnutrisi kalori-protein yang hebat beresiko kematian, dan memerlukan perawatan yang cermat di rumah sakit. Anak dengan status gizi kurang sebaiknya mendapat perhatian dari ibu maupun petugas agar tidak terjadi gizi buruk. Sebagian besar masyarakat yang mempunyai Balita gizi kurang melakukan perawatan sendiri di rumah sangat beresiko karena tidak semua ibu/ kepala keluarga mempunyai keahlian dalam merawat pasien gizi kurang. Untuk keberhasilan perawatan Balita gizi kurang di tingkat rumah tangga diperlukan partisipasi dari petugas kesehatan, hal ini dapat dilakukan oleh petugas kesehatan dengan memberikan bimbingan, bantuan dan pendampingan bagi keluarga melalui kunjungan rumah. Kunjungan rumah oleh petugas pada keluarga Balita dengan gangguan gizi, petugas dapat mengetahui permasalahan 
yang dihadapi keluarga dan membuat penatalaksanaan untuk gangguan status gizi Balita dengan memanfaatkan potensi keluarga dalam pemecahan masalah. Keluarga perlu disadarkan bahwa kesehatan mereka sepenuhnya berada di tangan mereka. Diwilayah kerja Puskesmas Cipanas Garut tahun 2016 kondisi tingkat pendidikan masyarakatnya rendah, dari jumlah penduduk 30.975 orang 32\% berpendidikan Sekolah LanjutanTingkat Pertama (SLTP). Jumlah Balita diwilayah ini cukup tinggi yaitu 3160 orang. Dari jumlah tersebut yang mengalami gizi kurang 325. Untuk mengatasi masalah tersebut, Puskesmas mempunyai kiat khusus melalui penerapan asuhan keperawatan keluarga. Tujuan mengetahui pengaruh asuhan keperawatan keluarga terhadap pengetahuan, sikap, asupan nutrisi dan status gizi Balita

\section{Metode Penelitian}

Penelitian ini merupakan quasi experimen dengan satu kelompok perlakuan dan satu kelompok kontrol. dengan jumlah populasi ibu yang mempunyai Balita gizi kurang untuk wilayah Puskesmas Cipanas adalah 325 orang, besaran sample 66 orang,kelompok perlakuan 66 orang, kelompok kontrol 65 orang.

Alat yang digunakan dalam pengumpulan data pada penelitian ini adalah 1) Formulir pertanyaan, 2) Alat ukur berupa dacin kapasitas $25 \mathrm{~kg}$ dengan ketelitian 0,1 $\mathrm{kg}$, 3)Papan ukur panjang badan Balita dengan ketelitian $0,1 \mathrm{~cm}$ dan microtoice dengan ketelitian $0,1 \mathrm{~cm}, 4)$ Formulir recall 24 jam, 5)Formulir kuesioner data dasar yang berisi identitas responden, 6)Lembar informedconsent. Penelitian ini memerlukan waktu 4 minggu

\section{Hasil}

Tabel 1.Pengukuran Pengetahuan Orang TuaBalita sebelum dan Sesudah Perlakuan

\begin{tabular}{llccl}
$\begin{array}{c}\text { Pengetahuan } \\
\text { Orang tua }\end{array}$ & $\begin{array}{c}\text { Kelompok } \\
(\mathrm{n}=66)\end{array}$ & $\begin{array}{c}\text { Kontrol } \\
(=65)\end{array}$ & $\begin{array}{c}\text { Statistik } \\
\text { Uji }\end{array}$ & Nilai $\mathrm{p}$ \\
\hline 1. Sebelum Perlakuan & $68,86(17,7)$ & $64,31(15,6)$ & $\mathrm{t}=1,56$ & 0,121 \\
$\begin{array}{l}\text { x (SD) } \\
\text { Rentang }\end{array}$ & $20,0-100,0$ & $20,0-95,0$ & &
\end{tabular}

2. Sesudah Perlakuan

\begin{tabular}{lllll}
$\mathrm{x}(\mathrm{SD})$ & $82,95(18,4)$ & $64,45(13,8)$ & $\mathrm{t}=6,62$ & 0,000 \\
Rentang & $30,0-100,0$ & $20,0-90,0$ & & \\
\hline Statistik Uji & $\mathrm{t}=5,09$ & $\mathrm{t}=0,09$ & \\
Nilai p & 0,000 & 0,929 & \\
\hline Rata -rata & &
\end{tabular}

Rata -rata

\begin{tabular}{cllllll} 
Perubahan & $28,85 \%$ & $3,22 \%$ & $\mathrm{Z}=4,02$ & 0,000 & \\
\hline Dalam & penelitian & ini menunjukan & ibu menujukan ada peningkatan,hal ini
\end{tabular} gambaran tingkat pengetahuan ibu. sesuai dengan tiori yang dikemukakan oleh Berdasarkan tabel 1.Skor pengetahuan Notoatmodjo ${ }^{[2]}$ Upaya-upaya agar orang tua Balita mengenai Gizi pada masyarakat berperilaku sesuai kesehatan kelompok perlakuan paling tinggi adalah maka perlu dilakukan cara imbauan, ajakan, kategori cukup baik sebanyak 33 orang bujukan dan persuasi untuk menyadarkan setelah diberikan asuhan selama satu bulan melalui pendekatan pendidikan meningkat menjadi kategori sangat baik, kesehatan.Sedangkan menurut hasil sebanyak 40 orang. Sedangkan pada penelitian Ardayani ${ }^{[3]}$ terdapat perbedaan kelompok kontrol sebelum penelitian pengetahuan ibu sebelum dan sesudah didominasi cukup baik 46 orang, setelah dilakukan pendidikan kesehatan, meningkat satu bulan terjadi peningkatan 1 orang 9,84.terjadinya peningkatan pengetahuan menjadi 47 orang.Gambaran pengetahuan ibu dapat berdampak pada merubah 
kebiasaan, membentuk kepercayaan dan persepsi. Peningkatan pengetahuan responden setelah diberi penyuluhan, penyuluhan secara langsung lebih efektif dan lebih memotivasi sasaran untuk mengadopsi materi penyuluhan. Ini sesuai dengan hasil penelitian $\operatorname{Ningsih}_{(4)}$ yang dilakukan di Desa Sumurgung Kecamatan Palang Kabupaten Tuban menunjukkan bahwa dari dari 20 responden sebagian besar 10 responden $(50 \%)$ berpengetahuan sedang dan status gizi toddler kurang, dan 4 responden (20\%) berpengetahuan kurang dan status gizi toddler buruk.

$\underline{\text { Tabel 2.Pengukuran Sikap orang tua Balita Sebelum dan Sesudah Perlakuan }}$

\begin{tabular}{|c|c|c|c|c|}
\hline \multirow[b]{2}{*}{ Orang Tua } & \multicolumn{2}{|c|}{$\underline{\text { Kelompok }}$} & \multirow{2}{*}{\multicolumn{2}{|c|}{ Statistik }} \\
\hline & $\begin{array}{l}\text { Perlakuan } \\
(\mathrm{n}=66)\end{array}$ & $\begin{array}{l}\text { Kontrol } \\
(\mathrm{n}=65)\end{array}$ & & \\
\hline $\begin{array}{l}\text { 1. Sebelum Perlakuan } \\
\mathrm{x}(\mathrm{SD}) \\
\text { Rentang }\end{array}$ & $\begin{array}{l}51,23(9,5) \\
28,6-67,0\end{array}$ & $\begin{array}{l}48,75(10,4) \\
28,6-73,4\end{array}$ & $\mathrm{t}=1,42$ & 0,157 \\
\hline $\begin{array}{l}\text { 2. Sesudah Perlakuan } \\
\mathrm{x}(\mathrm{SD}) \\
\text { Rentang }\end{array}$ & $\begin{array}{c}54,52(7,9) \\
35,8-63,7\end{array}$ & $\begin{array}{l}45,41(9,9) \\
22,6-68,0\end{array}$ & $\mathrm{t}=5,84$ & 0,000 \\
\hline $\begin{array}{l}\text { Statistik } \\
\text { Nilai p }\end{array}$ & $\begin{array}{l}t=2,48 \\
0,016\end{array}$ & $\begin{array}{l}Z=2,16 \\
0,031\end{array}$ & & \\
\hline $\begin{array}{l}\text { Rata -rata } \\
\text { Perubahan }\end{array}$ & $9,49 \%$ & $-2,31 \%$ & $t=2,52$ & 0,013 \\
\hline
\end{tabular}

Sikap orang tua Balita mengenai pengolahan makanan dan Perawatan balita Gizi kurang pada kelompok perlakuan meningkat $9,49 \%$ dari skor semula dan pada kelompok kontrol menurun 2,31\% dari skor semula Melihat hasil penelitian terhadap 66 orang Balita yang gizi kurang ternyata setelah dilakukan asuhan terdapat peningkatan asupan nutrisi . Gambaran sikap ada peningkatan $9,49 \%$ sehingga berdampak pada peningkatan asupan nutrisi. Hal ini sesuai dengan tiori yang dikemukakan oleh Basderel Munir ${ }^{[5]}$ sikap merupakan kecenderungan seseorang untuk menginterpretasikan sesuatu dan bertindak atas dasar interpretasi yang telah diciptakannya. Menurut hasil penelitian Ningsih ada hubungan antara sikap ibu dalam pemberian nutrisi dengan status gizi kurang anak usia toddler,begitu juga dengan penelitian yang dilakukan oleh Ardayani ${ }^{[3]}$ sikap ibu dari tidak mendukung menjadi mendukung dengan nilai terendah 45 dan tertinggi 51. Hasil penelitian Sumiati astute $^{[6]}$ salah satu faktor yang berperan dalam perubahan sikap adalah pengetahuan yang dimiliki, karena dengan pengetahuan akan berdampak pada terbentuknya sikap.

Tabel 3.Pengukuran Asupan Kalori Balita sebelum dan sesudah Perlakuan

\begin{tabular}{|c|c|c|c|c|}
\hline \multirow{3}{*}{ Asupan Kalori } & \multicolumn{2}{|c|}{ Kelompok } & \multirow{2}{*}{\multicolumn{2}{|c|}{ Statistik }} \\
\hline & \multirow{2}{*}{$\begin{array}{l}\text { Perlakuan } \\
\quad(\mathrm{n}=66)\end{array}$} & \multirow{2}{*}{$\begin{array}{c}\text { Kontrol } \\
(n=65)\end{array}$} & & \\
\hline & & & Uji & Nilai $p$ \\
\hline 1. Sebelum Perlakuan & & & & \\
\hline $\mathrm{x}(\mathrm{SD})$ & $55,29(8,4)$ & $57,12(6,9)$ & $\mathrm{t}-1,41$ & 0,160 \\
\hline Rentang & $36,4-74,7$ & $41,7-71,4$ & & \\
\hline 2. Sesudah Perlakuan & & & & \\
\hline $\mathrm{x}(\mathrm{SD})$ & $59,04(10,8)$ & $57,80(7,7)$ & $\mathrm{t}=0,77$ & 0,445 \\
\hline Rentang & $39,2-104,0$ & $39,2-104,0$ & & \\
\hline Statistik Uji & $\mathrm{t}=4,62$ & $\mathrm{t}=0,56$ & & \\
\hline Nilai p & 0,000 & 0,578 & & \\
\hline $\begin{array}{l}\text { Rata-rata } \\
\text { perubahan }\end{array}$ & $6,92 \%$ & $2,10 \%$ & $\mathrm{t}=2,01$ & 0,048 \\
\hline
\end{tabular}

Asupan kalori setelah satu bulan perlakuan pada kelompok perlakuan menjadi 59,04

dan kelompok kontrol 57,80. Rata-rata asupan kalori yang dikonsumsi Balita pada 
awal Gambaran asupan kalori dan protein $(\mathrm{p}<0,05)$ pada kelompok perlakuan, tetapi tidak signifikan pada kelompok kontrol $(p>0,05)$.Hasil analisis bivariat menunjukkan bahwa asupan makanan (energi dan protein) berhubungan dengan status gizi balita. Balita yang status gizinya normal, sebagian besar mempunyai asupan makanan yang cukup. Menurut hasil penelitian Purwaningrum ${ }^{[7]}$ bahwa nutrisi berdampak secara langsung terhadap status gizibalita yang mendapatkan asupan makanan kurang, mempunyai peluang mengalami status gizi tidak normal atau salah sebesar 2,872 kali lebih besar dibandingkan dengan balita yang cukup mendapatkan asupan makanan .Hasil analisis bivariat menunjukkan bahwa asupan makanan (energi dan protein) berhubungan dengan status gizi balita. Balita yang status gizinya normal, sebagian besar mempunyai

Tabel 4. Hasil Pengukuran Perubahan Tinggi Badan Balita Sebelum dan Sesudah Perlakuan

\begin{tabular}{|c|c|c|c|c|}
\hline \multirow{3}{*}{ Tinggi Badan } & \multicolumn{2}{|c|}{ Kelompok } & \\
\hline & \multirow{2}{*}{$\begin{array}{l}\text { Perlakuan } \\
(\mathrm{n}=66)\end{array}$} & \multirow{2}{*}{$\begin{array}{c}\text { Kontrol } \\
(n=65)\end{array}$} & & \\
\hline & & & \multicolumn{2}{|c|}{$\begin{array}{l}\text { Statistik } \\
\text { Uji } \quad \text { Nilai } p\end{array}$} \\
\hline \multicolumn{5}{|l|}{ 1. Sebelum Perlakuan } \\
\hline $\mathrm{x}(\mathrm{SD})$ & $80,80(9,0)$ & $83,37(12,4)$ & $\mathrm{t}=1,36$ & 0,176 \\
\hline Rentang & $63-100$ & $49-115$ & & \\
\hline \multicolumn{5}{|l|}{ 2. Setelah Perlakuan } \\
\hline $\mathrm{x}(\mathrm{SD})$ & $81,34(8,9)$ & $83,59(12,2)$ & $\mathrm{t}=1,21$ & 0,230 \\
\hline Rentang & $65-100$ & $49-115$ & & \\
\hline Statistik Uji & $\mathrm{Z}=3,22$ & $Z=2,91$ & & \\
\hline Nilai $\mathrm{p}$ & 0,001 & 0,004 & & \\
\hline Rata-rata Perubahan & $0,70 \%$ & $0,30 \%$ & $\mathrm{Z}=2,33 \quad 0,02$ & \\
\hline
\end{tabular}

Tabel 5. Hasil Pengukuran Berat Badan Balita Sebelum dan Sesudah Perlakuan

\begin{tabular}{|c|c|c|c|c|}
\hline \multirow{3}{*}{ Berat Badan } & \multicolumn{2}{|c|}{ Kelompok } & \multirow{2}{*}{\multicolumn{2}{|c|}{ Statistik }} \\
\hline & \multirow{2}{*}{$\begin{array}{c}\text { Perlakuan } \\
(\mathrm{n}=66)\end{array}$} & \multirow{2}{*}{$\begin{array}{l}\text { Kontrol } \\
(n=65)\end{array}$} & & \\
\hline & & & Uji & Nilai $\mathrm{p}$ \\
\hline 1. Sebelum Perlakuan & & & & \\
\hline $\mathrm{x}(\mathrm{SD})$ & $10,15(1,7)$ & $9,88(1,4)$ & $\mathrm{t}-0,97$ & 0,333 \\
\hline Rentang & $7,0-13,4$ & $7,3-13,0$ & & \\
\hline 2. Sesudah Perlakuan & & & & \\
\hline $\mathrm{x}(\mathrm{SD})$ & $10,46(1,7))$ & $9,93(1,4)$ & $\mathrm{t}=1,94$ & 0,054 \\
\hline Rentang & $7,5-13,8$ & $7,4-13,0$ & & \\
\hline Statistik & $\mathrm{t}=12,33$ & $\mathrm{Z}=2,07$ & & \\
\hline Nilai p & 0,000 & 0,038 & & \\
\hline Rata-rata & & & & \\
\hline Perubahan & $3,22 \%$ & $0,58 \%$ & $\mathrm{t}=7,10$ & 0,000 \\
\hline
\end{tabular}

Tabel 6. Pengukuran Status Gizi Balita sebelum dan sesudah Perlakuan pada kedua kelompok

$$
\text { Kelompok }
$$




\begin{tabular}{|c|c|c|c|c|}
\hline \multirow[t]{2}{*}{ Z-Score } & \multirow{2}{*}{$\begin{array}{c}\text { Perlakuan } \\
(\mathrm{n}=66)\end{array}$} & \multirow{2}{*}{$\begin{array}{l}\text { Kontrol } \\
(\mathrm{n}=65)\end{array}$} & \multicolumn{2}{|c|}{ Statistik } \\
\hline & & & Uji & Nilai $\mathrm{p}$ \\
\hline $\begin{array}{l}\text { 1. Sebelum Perlakuan: } \\
\mathrm{x} \text { (SD) }\end{array}$ & $-2,29(0,59)$ & $-2,06(0,58)$ & $Z=0,44$ & 0,657 \\
\hline Rentang & $-4,75-0,24$ & $-4,44-0,10$ & & \\
\hline $\begin{array}{l}\text { 2. Sesudah Perlakuan: } \\
\text { x (SD) } \\
\text { Rentang }\end{array}$ & $\begin{array}{l}-2,26(0,46) \\
-3,59-0,31\end{array}$ & $\begin{array}{c}-2,22(0,46) \\
-3,59-0,31\end{array}$ & $Z=3,08$ & 0,002 \\
\hline $\begin{array}{l}\text { Statistik Uji } \\
\text { Nilai p }\end{array}$ & $\begin{array}{l}Z=6,67 \\
0,000\end{array}$ & $\begin{aligned} Z=2,16 \\
0,031\end{aligned}$ & & \\
\hline $\begin{array}{l}\text { Rata-rata } \\
\text { Perubahan } \\
\end{array}$ & 0,23 & 04 & $t=7,15$ & 000 \\
\hline
\end{tabular}

Setelah Asuhan Keperawatan diberikan baik oleh Mahasiswa maupun dengan Tatalaksana rutin oleh Petugas Kesehatan. Selain ketahanan pangan, pola asuh merupakan salah salah faktor yang sangat berperan dalam meningkatkan status gizi Balita seperti hasil penelitian Putri, pola asuh merupakan faktor yang berhubungan dengan status gizi balita, begitu juga dengan hasil penelitian Merriyana ${ }^{[9]}$ pola asuh yang kurang baik,menyebabkan balita kurang mendapat asupan makanan yang bergizi, bervariasi, berimbang yang mengakibatkan gangguan pertumbuhan sehingga balitamenjadi pendek dan sangat pendek (Stunting Ketersediaan pangan tingkat rumah tangga merupakan penyebab langsung dalam kecukupan nutrisi. Menurut Laraeni $^{[10]}$ Program pendampingan gizi meningkatkan pengetahuan ibu, pola pengasuhan dan status gizi balita KEP diperlukan waktu 3 bulan.Menurut WHO dalam intervensi gizi buruk apabila terjadi peningkatan berat badan lebih dari 10 gram/kg BB/ hari maka peningkatan berat badan tergolong baik.Peningkatan status gizi Balita yang mendapat asuhan keperawatan keluarga dimungkinkan karena pengaruh meningkatnya pengetahuan ibu dalam pengelolaan makanan dan perawatan Balita gizi kurang.

\section{Kesimpulan}

Ibu Balita yang mendapat asuhan keperawatan lebih baik dibandingkan ibu yang tidak mendapat asuhan keperawatan keluarga.2) Sikap ibu Balita yang mendapat asuhan keperawatan keluarga lebih baik dibandingkan ibu yang tidak mendapat asuhan keperawatan keluarga.3). Asupan kalori protein Balita gizi kurang yang ibunya mendapat asuhan keperawatan keluarga lebih tinggi dibandingkan Balita yang ibunya tidak mendapat asuhan.4) Status gizi Balita yang ibunya mendapat asuhan

keperawatankeluargaterjadipeningkatan

Untuk merubah pengetahuan dan sikap ibu diperlukan waktu dan upaya-upaya yang lebih intensif. Ibu yang sudah mendapat Asuhan, pengetahuan dan sikap ibu masih labil perlu pembinaan oleh staf Puskesmas agar memperkuat baik pengetahuan maupun sikap sehingga perilakunya tidak kembali, begitu juga Balitanya selain meningkatkan mutu gizi juga tetap diberi asuhan bekerjasama dengan kader Posyandu sebagai pemantau langsung dilapangan agar terdeteksi secepatnya apabila ada perubahan

\section{Daftar Pustaka}

[1] Profil Data Kesehatan Kabupaten Garut. 2015.

[2] Notoatmodjo Soekijo. 2003. Pendidikan Dan Perilaku Kesehatan, Jakarta: Rineka Cipta.

[3] Ardayani, T. 2015. Pengaruh Pendidikan Kesehatan Terhadap Pengetahuan dan Sikap Ibu dalam Pencegahan Diare pada Balita di Kelurahan Cibaduyut Bandung. Kartika Jurnal Ilmiah Farmasi, Vol. 3. No. 1. Hal. 29-35.

[4] Ningsih, S., Kristiawati, K. I. 2014. Hubungan Perilaku Ibu dengan Status Gizi Kurang Anak Usia Toddler. Jurnal Pediomaternal. Vol. 3. Hal. 58-65. 
[5] Baderel, Munir. 1976. Mengintepretasi Sikap. Majalah Kesehatan. Hal. 52- 57.

[6] Astuti, S. 2013. Hubungan tingkat pengetahuan dan sikap masyarakat terhadap upaya pencegahan penyakit Tuberkulosis di rw 04 Kelurahan Lagoa Jakarta Utara.

[7] Purwaningrum, Sari, and Yuniar Wardani.2013. Hubungan Antara Asupan Makanan dan Status Kesadaran Gizi Keluarga dengan Status Gizi Balita di Wilayah Kerja Puskesmas Sewon I, Bantul. Jurnal Kesehatan Masyarakat. Vol. 6 No. 3

[8] Rahim, Fitri Kurnia.2014. Faktor Risiko Underweight Balita Umur 759 bulan. Jurnal Kesehatan Masyarakat. Vol. 9. No. 2. Hal. 115121.

[9] Merryana, A \& Vita, K. 2013. Pola Asuh makan pada Balita dengan status gizi kurang di Jawa Timur, Jawa Tengah dan Kalimantan Tengah. Buletin Penelitian Sistem Kesehatan. Vol. 16 No. 2. Hal. 185193.

[10] Laraeni, Y., Sofiyatin, R., \& Rahayu, Y. 2015. Hubungan Tingkat Pengetahuan, Sikap, dan Perilaku Ibu Terhadap Konsumsi Zat Gizi (Energi, Protein) pada Balita Gizi Kurang di Desa Labuhan Lombok. Media Bina Ilmiah. Vol. 15. No. 9. Hal. 1. 